\title{
Issues in Vocational Training Programs for the Female Prison Inmates in Sri Lanka: Trainers' Perspectives
}

\author{
E M V O Ekanayake*, L A Pavithra Madhuwanthi*** \\ * Department of Public Administration, University of Sri Jayewardenepura, Sri Lanka \\ DOI: 10.29322/IJSRP.11.06.2021.p11409 \\ http://dx.doi.org/10.29322/IJSRP.11.06.2021.p11409
}

\begin{abstract}
This study intends to explore the issues prevailing in the vocational training programs conducted for female prison inmates in Sri Lanka. This is a qualitative case study based on the vocational training programs conduct in two prisons in Sri Lanka. The study used semi-structured in-depth interviews which were conducted over the telephone with trainers who were engaged in providing vocational training programs for the female inmates in the two chosen prisons. Data collection was carried out during mid of 2020 and due to the Covid-19 pandemic, getting access to the trainers was highly restricted. Therefore, the study was limited to interview with only four trainers. Thematic analysis was used for data analysis. The trainers emphasized four main issues that they could experience in conducting the vocational training programs for the female prison inmates as: the variety of programs to be accessed by the inmates, willingness of female prison inmates to participate in the vocational training programs, tendency of trained self-employed female prison ex-inmates getting re-imprisoned, and issues faced by the prison trainers themselves.
\end{abstract}

Index Terms- Issues, Female prison inmates, Trainers, Vocational training programs

\section{INTRODUCTION}

$\mathrm{R}$ ehabilitation of the prison inmates is a major concern drawn by sociologists, legal practitioners and different activities in recent times. The imprisonment seizes the inmates within the walls of the prisons. But they should be explored to the world and should be given the opportunities to develop their potential to reintegrate to the society outside the prison walls. Inmates need education and training programs that not only teach them to read and write but also provide them with the necessary skills that promote a positive transition to society when they are released [1]. The provisioning of vocational training programs for inmates is one initiative for rehabilitation of prison inmates which will greatly support for inmates to strengthen their economic and social conditions upon getting released from the prison. Also it will help them to spend a quality time in the prison though they have been seized to receive a punishment.

In Sri Lankan context, the Department of Prisons conduct vocational trainings for the inmates. According to the performance report of Department of Prisons, Rs.3, 500, 000 was allocated for provisioning of vocational training for the prison inmates [2]. According to Kuruppu, there are wide variety of trainings are provided for the prisoners such as "carpentry, tailoring, laundry, motor mechanism, printing, bread making, weaving, knitting, masonry, soap making, mat making, brush making, polishing, tat making and the manu facture of coir goods for male inmates whilst the convicted female inmates are given training in various vocations such as tailoring, knitting, weaving and cookery" [3].

As in every other government program, the provisioning of vocational training programs for the inmates may also consists with its both efficiencies and inefficiencies. On one hand these programs may deliver effective output and on the other, there could be inefficiencies 
and negativities that hinder the effectiveness of these programs. Hence, the objective of the study is to identify issues prevailing in the vocational training programs conducted for the female prisoned inmates in Sri Lanka, from the trainers' perspective.

\section{LITERATURE REVIEW}

There are certain criticisms raised by different scholars over the barriers or the issues over conducting effective vocational training programs for the prison inmates. A study conducted in Nigeria found several issues in conducting vocational training programs for the prison inmates. They can be described as, inadequate support from government and other agencies for the promotion of rehabilitation of prison inmates through vocational skills acquisition programs, lack of inmates' will to participate in these programs, inadequate market for disposing the prison inmates' trade produces within and outside the prison wall, inefficient management, inadequate modern vocational training workshops and modern training equipment for the rehabilitation of prison inmates [4].

A research by Krienert in US on "Bridging the Gap between Prison and Community Employment" reveals that, the most states reported little to no vocational programs that linked directly to jobs in the community. And they do not have a comprehensive program that involves networking with community businesses. However, it was completely 'in-house'; the link to the outside community was missing [5]. Providing vocational training in the prison is more concerned about providing employment opportunities to the inmate once they are getting released and just only providing the in- house training rather linking these trainings to the jobs in the community, not lead to an effective conduct of these programs.

The study on "Acquisition of vocational trades by inmates in Nigerian prisons in Rivers State" has experienced several issues such as lack of counselor to guide the inmates on vocational choice, poor training facilities, over population of the inmates and the unqualified vocational instructors etc. [6]. And the limited opportunities given to offenders to participate in meaningful work or vocational education while in prison, terms of imprisonment which disrupt chances for developing work skills and experience, Prolonged imprisonment—as time spent in prison increases, the likelihood of participating in the legal economy decreases are identified as certain issues in conducting vocational training programs for inmates [7].

Victor Callan and John Gardner have found that there was an issue with getting access to skilled external trainers to conduct the vocational trainings in the prisons as it was a major challenge for centers to find staff who are willing to work at the pay levels set by the government. And they suggested having at least two trainers to be present to conduct workplace assessments. One is required to supervise prisoners, as the other works with individual prisoners completing assessment tasks [8]. Accordingly, it can be stated that by having less competent and unskilled trainers and having them in an inadequate number will not give effective results as it is intended to achieve.

Niriella, has emphasised several issues with regard to rehabilitation programs in Sri Lankan prisons which are also applicable to provisioning of vocational training programs in the prisons. "Lack and bad conditions of institutes, overcrowding of these centers, difficulties in providing proper care and protection to the inmate delinquents, difficulties in providing the required standards of privacy, inadequacy of separation of inmates in accordance with the international standards, difficulties in conducting the treatment programs in a proper manner, the existing rehabilitation methods do not adequately meet the needs of the inmates, financial constraints of running good rehabilitation programs and lack of sufficient, efficient and trained staff" are certain issues that can be seen in the Sri Lankan prisons context [9]. 
When it referring to the female prison inmates, they may face several other issues than the ones discussed above, over their participation in vocational education conducts in the prison. Because of the minority status of the females in prisons or may be due to the traditional view that women don't need vocational training or education, educational and other services for female inmates have been slow to develop. In many places, programs are still wholly inadequate [10].

In their study on women prisoners, Hamlyn and Lewis found that the majority of prisoners were engaged in the most common prison jobs which involved helping to run and maintain the prison; for example, cleaning, kitchens/serving and gardening and relatively few women prisoners were involved in work which served the needs of the outside [11]. The less engagement in outside-related vocational training programs due to the participation in in-house programs will limit female inmates' opportunity to acquire new skills.

With special reference to the vocational training programs in Sri Lankan context, Thilanka has mentioned that the there is a practice of providing vocational training based on gender differences. "Male prisoners have access to number of programs such as Masonry, Carpentry, Electrical wiring, Plumbing, House wiring, Coir work, baking industry etc. Though these are not recommended to seg regate gender wise, females are delivered just a handful of trainings compared to males in practice such as sewing, beauty culture, garments, weaving etc. which are stereotyped as females' work" [12]. Here it is evident that the female inmates are entitled to participate in works that are labeled as females' work. And they are not encouraged to go beyond the scope of housewives or housemaids.

\section{Methodology}

This is a qualitative study which was based on the vocational training programs conducted in two prisons in Sri Lanka which will refer as prison 1 and prison 2 hereinafter. In the year 2019, the direct admissions of female inmates to the prisons recorded as 612 and 461 for prison 1 and prison 2 respectively [13]. With reference to the provisioning of vocational training programs for the female inmates, it was found that in the prison 1, sewing and handicrafts trainings were given to the female inmates prior to the Covid-19 pandemic. However, the female ward of prison 1 is currently being moved away due to certain health and safety concerns. Prison 2 is mainly offering sewing, batik creations and weaving trainings for the female prison inmates. A sample of four trainers engaged in providing vocational training programs for the female prison inmates in the two chosen prisons was selected using purposive sampling method (Table 1). The study used primary data and the data collection was done using the telephone interview method with the use of a semistructured interview guide. This study allowed the participants to express their insights openly. The thematic analysis used to identify the key issues about the vocational training programs conducted in selected prisons in Sri Lanka. 
Table 1- Sample profile

\begin{tabular}{|c|c|c|c|c|c|}
\hline $\begin{array}{l}\text { Participants } \\
\text { (Trainers) }\end{array}$ & $\begin{array}{l}\text { Type of } \\
\text { employment }\end{array}$ & $\begin{array}{ll}\text { Years of } \\
\text { service }\end{array}$ & Qualifications & $\begin{array}{l}\text { Number of } \\
\text { trainees under } \\
\text { the supervision }\end{array}$ & Types of training provide \\
\hline $\begin{array}{l}\text { Participant } 1 \\
\text { (Prison 1) }\end{array}$ & $\begin{array}{l}\text { Employed by a } \\
\text { NGO }\end{array}$ & 3 years & $\begin{array}{l}\text { Followed patchwork, } \\
\text { hand embroidery and } \\
\text { tailoring courses }\end{array}$ & 16 & $\begin{array}{l}\text { Paper crafts, Bag creation, } \\
\text { Ribbon works, Pillow case } \\
\text { designing }\end{array}$ \\
\hline $\begin{array}{l}\text { Participant } 2 \\
\text { (Prison 1) }\end{array}$ & $\begin{array}{l}\text { Vocational } \\
\text { instructor } \\
\text { (VI) }\end{array}$ & 5 years & $\begin{array}{l}\text { Followed a dress } \\
\text { making/tailoring course }\end{array}$ & 15 & $\begin{array}{l}\text { Saree jacket, Skirts, Baby suits, } \\
\text { Night dresses }\end{array}$ \\
\hline $\begin{array}{l}\text { Participant } 3 \\
\text { (Prison 2) }\end{array}$ & $\begin{array}{l}\text { A jailor specially } \\
\text { trained for } \\
\text { conducting the } \\
\text { trainings }\end{array}$ & 6 years & $\begin{array}{l}\text { Followed a batik and a } \\
\text { tailoring courses }\end{array}$ & 20 & $\begin{array}{l}\text { Batik saree, Lungi, Batik } \\
\text { sarongs, Batik housecoats }\end{array}$ \\
\hline $\begin{array}{l}\text { Participant } 4 \\
\text { (Prison 2) }\end{array}$ & $\begin{array}{l}\text { Vocational } \\
\text { instructor } \\
\text { (VI) }\end{array}$ & 5 years & $\begin{array}{lll}\text { Completed } & 2 & \text { years } \\
\text { diploma } & & \end{array}$ & 33 & $\begin{array}{l}\text { Handloom sarees, lungi, Suits } \\
\text { of the inmates, Towels }\end{array}$ \\
\hline
\end{tabular}

\section{FINDINGS}

During the process of interview with participants to the study, the researchers could identify four main issues relating to the conduct of vocational training programs to the female prison inmates in Sri Lanka. They are: issues regarding the variety of programs to be accessed by the inmates, willingness of female prison inmates to participate in the vocational training programs, tendency of trained self-employed female prison ex-inmates getting re-imprisoned and issues faced by the trainers themselves.

\section{Issues regarding the variety of programs to be accessed by the female prison inmates}

It could be found that the female inmates are only having the access to work stereotyped as female work. In previous studies they have shown a tendency that in the vocational training programs for the inmates, women inmates were mainly trained to sew, cook and wait on tables. But after the release from the prison such jobs offer minimal opportunity for self-support [14].

And there are many other programs that could be offered for the female inmates such as shoe making, soap makings, incense stick making and many other programs which are simple and easy for the female inmates to practice. But, in Sri Lankan context it is found that the female inmates are mainly entitled to engage in the works stereotyped as female works such as sewing, arts and crafts, weaving and batik works.

"In the prison where I work, male inmates are engaged in more vocational practices than the female inmates such as tailoring, weaving, metal works, carpentry and coir products creation. According to my point of view the coir products manufacturing can be also offered to the female inmates. And they could manufacture floor mats, brushes, brooms using coir. And these types of products are not much difficult for the females to manufacture" (Participant 3). 
And she further added that the female inmates can utilize their free time to manufacture those coir products as they can create those coir products even within their prison cells.

Another issue emphasized by the trainers is the less recognition for the interest of the inmates in conducting the vocational training programs. Even though the female inmates are having particular interests over some training programs, the prison authority is more prioritizing about the trainings that they could find the resources and trainers easily.

As stated by the participant 2, most commonly females are very interested about the beauty cultural programs. Though there was a beauty cultural program conducted in the prison she worked, it had not continued for a long due to some internal issues.

"Female inmates had highly embraced the beauty cultural training and enjoyed sessions by doing the makeups and hair cuttings with their co-inmates and once the training was terminated the most of the inmates who took that training got disappointed" (Participant 2)

And it could be found that, when designing the types of training programs to be offered to the female inmates the relevant authorities have missed certain effective training programs which can be supported with the inherent skills of women. For an example, as most of the female inmates are good at cooking there could be special trainings designed for them to increase their cookery skills. Thereby they could engage in some self-employment opportunity by using the own styles and the knowledge improved through the vocational training programs. But there was no any type of cookery trainings to be found among the vocational training programs provided for the female inmates.

"There are many market opportunities which are related to the cookery and many types of trainings are there to be offered such as making of canned food products, snacks and various other simple products” (Participant 3).

Accordingly, it can be viewed that there are some issues relate to the varieties of the vocational trainings programs offered to the female inmates such as many of these trainings offered to the female inmates are stereotyped as female works and less concern over the inmates' preferences and their skills when designing the vocational trainings for the inmates.

\section{Issues about willingness of female prison inmates to participate in the vocational trainings programs}

When referring to the number of the total female prison population in the prison including the both convicted and remand inmates it could be observed relatively a small percentage of female inmates who are taking the trainings. In the both prisons, there were female inmates more than hundred including both convicted and remand inmates. However, as stated by the all four participants to the study, only about 10 to 30 inmates in the prisons were taking part to these vocational training programs.

"The custody over the remand inmates is vested with the courts and the prison department is only having the custody of the convicted prisoners. So we cannot compel the remand inmates to take these trainings. But if they are having an interest to participate we could give them an opportunity” (Participant 2).

Accordingly, it can be viewed that the rest of the inmates, specially the remand inmates who are not taking the trainings, have no any motivation or willingness to acquire new knowledge even though they are invited to take the trainings. It may be due to the relatively low period time they have to stay in the prison. But the relevant authorities could encourage them to take these trainings as the inmates 
could gain various benefits from these. And also when the number of the participants gets increased much effective outcome could be obtained.

Even though the majority of the inmates who participating to the vocational training programs are with a higher level of interest and motivation to take the classes there are few inmates who taking these classes just to spend the time. And they have no intention to grab the knowledge or to learn new things.

"There are some inmates who coming to the classes just to spend their time and not actively participate to the activities and sometimes it caused disturbances" (Participant 2).

This behavior of the inmates will create ineffectiveness in these trainings as those inmates may utilize the resources in vain, their coinmates may lose their attention and the motivation of the trainers may get reduced too.

\section{Tendency of trained self-employed female prison ex-inmates getting re-imprisoned}

One of the main aims of providing the vocational training is to direct the inmates for building their economic status by their own and giving them a meaningful life style which keep them away from the illegal activities. And it could be achieved to a certain level when the ex-inmates get a job or engage in self-employment activities. In the interviews it was found that the trainers have no any records about the ex-inmates' activities with themselves. But as per their personal experiences, participant 1 and 2 disclosed there are some inmates who are taking the advantage of these training programs. But unfortunately, among those ex-inmates once self-employed, there were some inmates who again got imprisoned.

There it could be found that, the ex-prisoners not getting the advantage from the things they learnt from these training programs.

"One was engaged in sewing bags as a self-employed ex-inmate. And she was an inmate who has been selected once as the best performer in the completion of my training program and she was been rewarded with a Juki machine and materials worth ten thousand rupees at the time when she got release from the prison. Though she has done this for a certain time period, now she is imprisoned again.” (Participant 1).

And it is evident that even though the inmates have their skills, talent, desire and the support from others to engage in self-employment opportunities inmates are not ready to get the benefit of the things they learned in the prison upon their post release lives. Then it can be considered as a fact that hinders the effectiveness of such programs.

She further added that,

"Many of the inmates are saying that, they not just even think of returning to their old illegal activities and never want to come back to the prison cell. But the very person known to me who was an inmate once selected as the best participant in my training program and who was engaged in a self-employment opportunity for short time period, now is in the prison again”.

And the participant 2 supported to that stating;

"Ex-inmates perceive that the income they received by putting a consider effort, time and resources on sewing and other self-employment activities, is less significant than the amount they received by selling drugs and engaging in other illegal activities". 
As the inmates returning to the same living pattern with the same associations, they are gradually getting used to the previous illegal activities. And they find that the income they received from these practices is more lucrative than the income from the fair livings with a self-employment activity. Because they do not have proper market opportunities to sell their products and the income they received through selling those products is relatively very low when it compared with production cost. Accordingly, the researchers could identify that there is a gap where the trained self-employed ex-inmates through the vocational training programs conducted in the prisons are getting imprisoned again even though they have the opportunity to utilize their learnt knowledge and practiced skills to a fair living.

\section{Issues faced by the prison trainers}

The participants in the study emphasized certain issues which are faced by themselves in conducting the vocational training programs in the prisons.

In order to deliver more effective training programs for the inmates an adequate number of qualified trainers should be there. When analyzing the qualifications of the four trainers in the study it is found that all of them are well qualified for delivering the vocational trainings for the inmates. But, as mentioned by the participants to the study an issue could be found in relation to the number of the available trainers for delivering theses trainings for the inmates. If the relevant authorities could employ more qualified trainers in different subject areas, it will lead to deliver different types of vocational training programs to the inmates. But in the study, it can be found that almost all four trainers are relating to same field of industry where the batik, weaving, tailoring can be categorized as textile industry.

Due to unavailability of the experienced trainers all four trainings programs identified in this study were carried out by a single trainer. And when it refers to the ratio of trainer to inmates, it could be observed that the training programs are having the ratios as i.e.; handicrafts training 1:16, tailoring program 1:15, batik training $1: 20$ and weaving training 1:33. There it could be stated that the trainer to inmate ratio is higher in both batik and weaving trainings than the handicrafts and tailoring training programs. Especially for the batik and the weaving trainings programs trainers have found it bit difficult to handle everything by their own. And they suggest it will be much convenient for them if there are any assistants for their work.

But, due to the limited funds allocations department of prisons is struggling in going for recruiting external resource personnel.

"According to my knowledge, in order to get the service from a well-qualified trainer from outside will cost around Rs. 3500 per day. And generally, a weaving course could be conducted for at least 3 months. There, a huge cost has to be incurred for getting the service from the outsiders" (Participant 4).

There, it could be stated that, mainly due to the deficiency in the prison staff than the required amount and the high cost involved in getting the support from the qualified trainers from the outside have caused for the issue of lower number of trainers available for conducting the vocational training programs for the inmates. And thereby it has been caused to increase the workload of the trainers and also increase the trainer to inmate ratio too. 


\section{DISCUSSION}

The findings of the study have compared and contrasted with similar studies and found that the four main issues identified in the study are most commonly discovered issues in conducting the vocational training programs for the prison inmates.

As identified by Hamlyn and Lewis [11] and in Sri Lankan context as per Thilanka [12], this study explored that the female prison inmates in the selected prisons are only offered with the vocational training programs stereotyped as female works. But it could be found that there are certain types of vocational training programs that could be offered to female inmates which are currently only offereing to male inmates. And also it is found that the almost all four training programs offered by the four trainers in the study which are more popular in Sri Lankan prisons can be categorised under the textile industry. But there could be more types of vocational training programs to be offred for the female prison inmates from different types of categories.

In a Nigerian study on vocational skills acquisition programs Mannir [4] has emphasised, lack of inmates' will to participate in these programs and inadequate market for disposing the prison inmates' trade produces within and outside the prison wall as two main issues in conducting those vocational skills acquisition programs. In the current study with special reference to vocational training progrmas conducted for the female prison inmates, could also identified that there are issues in inmates participation to the training programs where significantly low number of inmates out of total female prison populations in the respective prisons are taking part in such vocational training programs. And also the trainers emphasised that self-employed ex-inmates are struggling to earn a considerable income from the products they make. And the unavailability of proper market opportunities can be identified as a reason for that.

Moreover, the participants to the current study ellaborated that self-employed trainerd ex-inmates are again getting imprisoned by getting used to their previous illegal behavior patterns once they get released. And they may find the income they earn from illeagl activities are more lucrative than the income they receive from selling the products they make by utilizing their learned knowledge and improved skills.

According to Victor Callan and John Gardner, there is an issue over getting access to skilled external trainers to conduct the vocational trainings in the prisons because there is a challenge to find staff who are willing to work at the pay levels set by the government. And they suggested in order to deliver more effective training program, at least two trainers need to be present to conduct workplace assessments. One is required to supervise prisoners, as the other works with individual prisoners completing assessment tasks [8]. And this a most common issue emphasized by all four participants to the study as they find number of trainers to deliver vocational training programs in Sri Lankan prisons is inadequate. And there is financial constraint to access the qualified trainers too.

\section{CONCLUSION AND RECOMMENDATIONS}

This qualitative study explored issues prevailing in the vocational training programs conducted for the female prison inmates in Sri Lanka. The four trainers engaged in providing vocational training programs for the female prison inmates shared their perspectives on the issues they experienced in conducting the vocational training programs. Female prison inmates are offered with a limited variety of vocational training programs, relatively less number of inmates' participation to the vocational training programs, tendency of trained self-employed female prison ex-inmates getting re-imprisoned and the issues trainers face by themselves were the main findings of this study.

The researchers have come up with several recommendations to avoid the identified issues of vocational training programs delivered for the female prisoned inmates in Sri Lanka. The female inmates should be offered with different types of trainings beyond the existing 
gender stereotyped trainings. The relevant authorities can encourage more inmates' participation to the trainings. Government should establish a continuous follow up mechanism over ex-inmates and government can be more concerned in supporting self-employed exinmates. Recruiting qualified vocational instructors and providing special trainings for the trainers will make the vocational training programs more productive for the prisoners. And the prison authority could conduct these training programs in collaboration with different institutions which are engaging in providing vocational education.

\section{Limitations}

The main limitation in the study was that not being able to get the access to visit the prison premises and to collect the data directly from the participants. Due to the health precautions taken over the Covid-19 pandemic and the security measures in the prison premises have restricted access to visit the prison and physically conduct the interviews with the trainers. Therefore, it caused to limit the number of participants in the sample to four trainers. And also as those trainers were contacted over the phone, it was hard to have lengthy conversations and make observations to get the data from them despites their busy schedule.

\section{REFERENCES}

1. Mbatha, C. M., Kerre, B. W., Ferej, A., \& Kitainge, K. M. (2019). How Effective is Vocational Education and Training for Rehabilitation in Kenyan Prisons? A Study Protocol. American Journal of Educational Research, 7(10), 677-693.

2. Department of Prisons. (2019). Performance Report Department of https://www.parliament.lk/uploads/documents/paperspresented/performance-report-department-of-prison-2018.pdf

3. Kuruppu G. (2000). Current issues in correctional treatment and effective countermeasures.

4. Abba, M. (2016). Rehabilitation of Prison inmates through Vocational Skills Acquisition Programmes as perceived by prison officials in North-West States. Nigeria: Unpublished PhD Thesis: University of Nigeria, Nsukka, Enugu State, Nigeria.

5. Krienert, J. L. (2005). Bridging the Gap between Prison and Community Employment: An Initial Assessment of Current Information. Criminal Justice Studies, 18(4), 293-303.

6. Deebom, T., Kooli, P. L., \& Deebom, I. (2019). The Influence of Vocational Rehabilitation for Societal Re- Integration of Inmates in Nigerian Prisons in Rivers State. Asian Journal of Education and Social Studies, 3(3), 1-10.

7. Stephen, E. N., \& Dudafa, U. J. (2016). Prisons Rehabilitation Programmes in Nigeria: A Study of Inmates Perception in Okaka Prison, Bayelsa State. Studies in Sociology of Science, 7(6), 1-12.

8. Callan, V., \& Gardner, J. (2005). Vocational education and training for adult prisoners and offenders in Australia: Research readings. https://files.eric.ed.gov/fulltext/ED499730.pdf

9. Niriella, J. (2011). Rehabilitation and re-integration of juvenile offenders in Sri Lanka. US-China Law Review, 8, 499-509.

10. Newman, A. P. (1993). Prison Literacy: Implications for Program and Assessment Policy. https://eric.ed.gov/?id=ED363729

11. Hamlyn, B., \& Lewis, D. (2000). Women Prisoners: A Survey of Their Work and Training Experiences in Custody and On Release. Home Office Research Study. Research, Development and Statistics Directorate, Communications Development Unit, Home Office, Rm. 201, 50 Queen Anne's Gate, London SW1H 9AT.

12. Thilanka, W. A. S. (2017). Exclusion within Exclusion: Gender Stereotyping of Vocational Training in Prison. http://ir.kdu.ac.lk/handle/345/1871

13. Deartment of Prisons. (2020). Prison Statistics of Sri Lanka 2020. Statistics Division, Prisons Headquarters. http://prisons.gov.lk/old_web/Statistics/Statistics-2020.pdf

14. Morash, M., Haarr, R. N., \& Rucker, L. (1994). A Comparison of Programming for Women and Men in US Prison in the 1980s. Crime \& Delinquency, 40(2), 197-221.

\section{AuTHORS}

First Author - E M V O Ekanayake, Department of Public Administration, University of Sri Jayewardenepura, Sri Lanka, vinidaekanayake@gmail.com

Second Author - L A Pavithra Madhuwanthi, Department of Public Administration, University of Sri Jayewardenepura, Sri Lanka, pavithra@sjp.ac.lk 